\title{
BUILDING BILINGUAL BI-CONTINENTAL E-LEARNING COURSES
}

\author{
Zhanyang Zhang (zhangz@mail.csi.cuny.edu) \\ Roberta Marsha Klibaner (klibaner@mail.csi.cuny.edu) \\ Emile Chungtian Chi (chi@mail.csi.cuny.edu) \\ College of Staten Island, CUNY \\ Ke-Ping Yuan (yuankp@shtvu.edu.cn) \\ Shanghai TV University
}

\begin{abstract}
The authors have been actively engaged in E-learning starting in 1996, at the College of Staten Island, CUNY, a public university on the East coast and Shanghai Television University, an open university in Shanghai. We have reported on this work in [Chi, Klibaner, 1999, 2001, 2003]. This collaboration has been expanded to include a bilingual course offered simultaneously at both institutions. Of the many technical issues involved in such a simultaneous e-learning course, the time difference is the only one which remains immutable. This paper describes our experience with a hybrid course in Database Theory offered bilingually in Chinese and English and a Windows based terminal software laboratory.

Keywords: face to face (f2f), E-learning
\end{abstract}

As Asia continues to open its economy to the world, improved communication skills in English are essential to its ability to compete in the global economy. Many universities in Asia require a certain percentage of courses to be taught in English, bilingually, or to at least use an English textbook. For f2f courses, the ideal situation is to have a bilingual professor, with English as the primary teaching language. Students may ask questions in their native language, with explanations and discussions in both languages. However there are very few truly bilingual professors, especially in highly technical disciplines, such as computer science. To achieve this goal of providing a quality education for all each professor can (and did) produce a video of all lectures, which are available on the course website and can be reviewed at the students' convenience. Real-time video conferencing, which is being used this semester in our cross-cultural course provides an affordable solution to the multi-lingual problem.

We describe the design and use of bilingual web pages, PowerPoint presentations, and discussion boards. A virtual classroom and multi-media (posting of sound and video clips) were also used for this course. We discuss problems caused by differing linguistic abilities and the advantages and difficulties of bilingual e-learning vs. face-to-face (f2f f for advanced technical courses.

The expansion of available bandwidth and inexpensive video conferencing equipment will make it possible for The College of Staten Island, Shanghai TV University, and universities in 
Turkey and South Africa with funding from the United States Department of State to offer a cross-cultural video conference course to students in all four universities. With this technology we hope to fully harness the ability of distance learning to advance quality open education for all our students.

\section{BILINGUAL E-LEARNING ACROSS THE PACIFIC}

Introduction to Database is an essential course for computer science majors. For the last three years, we have taught it at both The College of Staten Island and Shanghai TV University as a hybrid distance-learning course. In the US, the course meets f2f at least 2 hours per week and as may meet f2f for 4 hours depending on student needs. The additional hours are for small group discussions or 1 on 1 . During this period we have explored the idea of developing a bilingual version of this course, in Chinese and English. This was inspired by our desire to serve two important groups of students:

- US students whose first language is not English. These students, who comprise about $30 \%$ of the class, can use all the ESL help they can get. For the most part, their computer skills exceed their English skills.

- Students in Shanghai who are interested in improving their English language skills. Better English considerably enhances their employment prospects and earning ability in Shanghai.

For e-learning courses, a bilingual professor can be simulated with two professors (who may be at the same campus or 10,000 miles apart), possibly bilingual, but at least one fluent in each language. The e-learning material can be enhanced with bilingual web pages. These web pages may be displayed in many ways.

During f 2 f lectures,

- a PowerPoint page may be split above and below

\section{Need for Complex Data. Types}

- Traditional database applications in data processing had conceptually simple data ty pes - Relational model suitable and $1 \mathrm{NF}$ holds

- Complex data ty pes have grown more important in recent years

- E.g. Addresses can be viewed as a - Single (complex) string, ar

Separate attributes for each part, or
- Composite (hierarchical) attributes (which are not $1 \mathrm{NF}$ )

- It is convenient to store multi-valued attributes without creating a separate relation to store the values in $1 \mathrm{NF}$

- Applications

- computer-aided design, computer-aided software engineering

- multimedia and image databases, and document/hypertext databases.

\section{复染数据类型的需要}

口 在数据处理中, 传统的数据库应用程序只有简单的数据类型

关系模型和满足1范式的关系模式所包含的数据类型

工在最近几年, 复杂数据类型变得尤为重要

- 例如, 地址可以视为一个

口单个 (复合) 字符串, 或

口每部分各成为单独的属性, 或

复合(结构)属性 (不属于范式) $1 \mathrm{NF}$ 的关系去存放这些值。

存储多

- 应用领域

- 计算机辅助设计 (CAD), 计算机辅助软件工程 (CASE)

- 多媒体图像数据库, 以及文档/超文本数据库。 
- $\quad$ Side by side

\section{Need for Complex Data Types 复染数据类型的需䍉}

- Traditional database applications in data processing had conceptually simple data types

- Relational model suitable and $1 \mathrm{NF}$ holds

- Complex data types have grown more important in recent years

- E.g. Addresses can be viewed as a - Single (complex) string, or

- Separate attributes for each part, or

- Composite (hierarchical) attributes (which are not 1NF)

- It is convenient to store multi-valued attributes without creating a separate relation to store the values in $1 \mathrm{NF}$

- Applications

- computer-aided design, computeraided software engineering

- multimedia and image databases, and document/hy pertext databases.
在数据处理中，传统的数据库应用程序 只有简单的数据类型

- 关系模型和满足 1 范式的关系模式所包 含的数据类型

口在最近几年，复杂数据类型变得尤为重 要

- 例如，地址可以视为一个

」单个 (复合) 字符串, 或

」每部分各成为单独的属性, 或

、复合(结构)属性 (不属于1范式)

- 存储多值属性很方便，不需要另建一个 1NF 的关系去存放这些值。

- 应用领域

- 计算机辅助设计 (CAD)，计算机辅助软 件工程 ( CASE )

多媒体图像数据库, 以及文档/超文本数 据库。

- Two large screen monitors or projectors on a computer equipped with two video cards may be used for two separate side by side PowerPoint presentations

\section{Need for Complex Data. Types}

- Traditional database applications in data processing had conceptually simple data types

- Relational model suitable and 1NF holds

- Complex data types have grown more important in recent years

- E.g. Addresses can be viewed as a

- Single (complex) string, or

- Separate attributes for each part, or

- Composite (hierarchical) attributes (which are not 1NF)

- It is convenient to store muti-valued attributes without creating a separate relation to store the values in $1 \mathrm{NF}$

- Applications

- computer-aided design, computer-aided sofware engineering

- multimedia and image databases, and document/hypertext databases. 


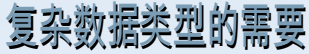

【在数据处理中，传统的数据库应用程序只有简单的数据类型

- 关系模型和满足 1 范式的关系模式所包含的数据类型

口在最近几年，复杂数据类型变得尤为重要

- 例如，地址可以视为一个

口单个 (复合) 字符串, 或

士每部分各成为单独的属性，或

。复合(结构)属性 (不属于1范式)

- 存储多值属性很方便, 不需要另建一个 $1 \mathrm{NF}$ 的关系去存放这些值。

」应用领域

- 计算机辅助设计 ( CAD), 计算机辅助软件工程 ( CASE)

- 多媒体图像数据度, 以及文档/超文本数据库。

- A wide screen projector enables side by side presentation on a single screen. The aspect ratio of a standard computer display is $4: 3$. Wide screen displays have an aspect ratio of $16: 10$, so if the screen is split each side has a ratio of $8: 10$ (the standard for printed material).

\section{Need for Complex Datia. Types}

ـ Traditional database applications in data processing had conceptually simple data types

- Relational model suitable and $1 \mathrm{NF}$ holds

- Complex data types have grown more important in recent years

- E.g. Addresses can be viewed as a

- Single (complex) string, or

- Separate attributes for each part, or

- Composite (hierarchical) attributes (which are not 1NF)

- It is convenient to store muti-valued attributes without creating a separate relation to store the values in $1 \mathrm{NF}$

- Applications

- computer-aided design, computer-aided software engineering

- multimedia and image databases, and document/hypertext databases. 


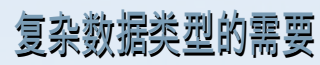

【在数据处理中，传统的数据库应用程序只有简单的数据类型

- 关系模型和满足 1 范式的关系模式所包含的数据类型

曰在最近几年, 复杂数据类型变得尤为重要

- 例如, 地址可以视为一个

口单个 (复合) 字符串, 或

。每部分各成为单独的属性, 或

、复合(结构)属性 (不属于1范式)

、存储多值属性很方便, 不需要另建一个 1 NF 的关系去存放这些值。

」应用领域

- 计算机辅助设计 ( CAD ), 计算机辅助软件工程 ( CASE)

- 多媒体图像数据库, 以及文档/超文本数据库。

For e-learning, side by side display of the web material on one screen at home will work best for the student. Side by side display of web material in two languages will help students who need to improve their ability in their second language as well as learn the course material. This material will be facilitated and enhanced by using wide screen displays which are now available at reasonable cost on laptop computers.

After experimenting with all of these formats, we have come to the conclusion that side by side web pages in Chinese and English were the most effective way to develop and present the course material in bilingual form. Good design of bilingual web material requires careful planning to create matching pages. This involves much more than language translation.

The presentation of both Chinese and English versions of the same web page will help facilitate and enhance the learning process for students with knowledge of both languages who have a deficiency or lack of fluency in one of them. This clearly extends to other languages and other courses. There is feedback in both directions. The bilingual web presentations help motivate students who study the advanced course material in their native language, to simultaneously improve their English. And, bilingual web pages will aid their learning of the very technical course material.

In the spring of 2004, the authors co-taught an advanced computer science elective, Advanced Database Topics, as a hybrid (half asynchronous and half f2f) course. The students in Shanghai are native Chinese speakers, with varying degrees of reading, writing and speaking ability in English. In New York the class was almost evenly divided between native English speakers and native Chinese speakers. 
The College of Staten Island supports Blackboard as an e-learning platform. At Shanghai TV University students and teachers use a remote software laboratory application based on WBT (Windows-Based Terminal). This system allows the installation of all required the laboratory software for all courses on a terminal server. Applications use the RDP (Remote Desktop Protocol) protocol to communicate between the terminal server and client (terminal user). The RDP clients are designed to efficiently transmit keyboard, mouse, and video information providing high-performance Windows presentation services over low-bandwidth connections. Users may log-on to the Terminal Server computer as an administrator, teacher or student, wherever and whenever they are. Administrators may remotely perform maintenance. Teachers may post, retrieve, grade and return laboratory assignments. Students have access to the laboratory software for their courses which permits them to complete and submit their assignments and receive their grades remotely. They may use this system to discuss problems with the assignments by sending messages to each other. The terminal users (administrator, teachers and students) don't have to install any of the required laboratory software on their own computer; by remotely logging on the terminal server of the university they have access to everything they need. The Chinese Ministry of Education has signed a contract to make Blackboard the distance learning system for all Universities in China, so future collaborations using the same e-learning software by both institutions will facilitate the development of bilingual material for e-learning.

In Blackboard lectures and PowerPoint presentations are presented to students under the Course Documents and Assignment tabs and students are encouraged to communicate via email and discussion board forums. Many theoretical topics are presented in this course and the instructors must devote much effort to involve students who are not initially familiar with an e-learning presentation.

With most ESL students, their English reading ability is far better than their oral ability. There is little or no problem for them to read textbooks and technical papers in English. An on-line class with Web posted teaching material may be to their advantage compared with a traditional f2f class taught in English.

Our experiences with this class is that e-learning works well for the dissemination of class materials, the case study, and the one-to-one communication related to the required course work. It is less successful in terms of communication using the discussion board and chat room.

At The College of Staten Island, the instructor finds that most students prefer f2f discussions in class to the discussion board or chat room despite the encouragement and the potential bonus points award for active online participations. A small number of students prefer private one-toone discussions with the instructor. We do not fully understand the reasons for this, but the following issues might directly or indirectly be involved.

- Communication - People communicate to each other using both verbal and body languages. E-learning blocks the communication channel of body language and leaves all the communications in verbal language mostly in written form. Due to the highly technical 
nature of this class, it seems essential for students to use all methods of communication to help them to formulate and communicate their ideas.

- Asynchronous vs. Synchronous communication - One thing the f2f communication does best is to support the flow of conversation, or the trend of thought. The "real time" interactive questions and responses are crucial in the communication dynamics during the discussion of abstract and difficult technical concepts. An asynchronous online discussion with delayed response interrupts the communication dynamics and breaks the trend of thought. The time zone difference adds to this problem.

- Language barrier - The level of foreign language skills required increases from reading to listening or speaking to writing. Writing is a creative activity that is more demanding, even in someone's native language. It might be easier for them to "talk" about their problems than express them in written form. Evidence to support this is the need for the instructor to spend more time answering questions for ESL students during f2f classes or office hours.

- Peer competition - Some student are reluctant to post their ideas and answers on discussion boards fearing that others might steal their ideas.

- "Students have different learning styles--characteristic strengths and preferences in the ways they take in and process information. Some students tend to focus on facts, data, and algorithms; others are more comfortable with theories and mathematical models.

Some respond strongly to visual forms of information, like pictures, diagrams, and schematics; others get more from verbal forms--written and spoken explanations. Some prefer to learn actively and interactively; others function more introspectively and individually."(Felder)

The following suggestions if implemented might provide some remedies for the above issues (we encourage a discussion on these at the conference).

Suggestion1 - Videoconference. As discussed above we have begun to implement videoconferencing this semester. The main difficulty has been attempting to overcome the time difference.

Suggestion2 - An on-line virtual classroom (chat). This also has the time zone problem. The current Blackboard implementation of the virtual classroom does not implement threads, so the chat can become very confusing.

Suggestion3 - Multimedia. Students can make sound clips or even video clips and upload them along with text messages when posting to the discussion board. We explored this approach in the Advanced Database class by using the sound recording and playing software included with Windows. It is very easy for student to use with following two steps. 
Step 1, Record the sounds with Microsoft Sound Recorder.

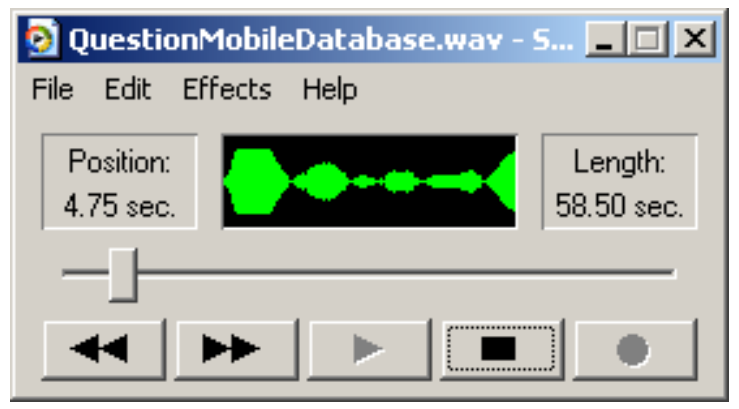

Step 2, Post the question with combination of text message and sound clip on the discussion board.

\section{Discussion Board}

44 Previous Message Next Message D)

Current Forum: Discussion on Mobile Database

Read 16 times

Date: Sun Apr 252004 2:39 pm

Author:

Attachment: questionmobiledatabase.wav (1290100 bytes)

Subject: Disk on Air Architecture for Mobile Database

In supporting mobile computing and mobile database, data dissemination plays an important role to distributed required data timely to mobile clients. This is a summary of the ideas behind disk on air architecture. I post it as a sound clip on the discussion board for further discussions.

44 Previous Message Next Message >

\section{Current Thread Detail:}

After the sound clip is posted, other students can read the message and play the sound clips within their web browser.

\section{CONCLUSION}

This bilingual e-learning project has completed its first semester. The data gathered is being analyzed and will be presented at the conference. It will include a summary and assessment of the semester's experience and a plan for the continuation of the project. At this juncture, we expect the assessment will show improved outcomes.

The two institutions participating in this project are both large urban universities. We share a common mission, which is to provide a well educated urban work force to support economic growth in the $21^{\text {st }}$ century. E-Learning is a vital platform for both universities to deliver quality education to large, diverse student bodies. 
To support our goal, we plan to continue work in the following areas

- Explore and evaluate proper e-learning technologies and platforms including Blackboard and WBT.

- Train the faculty from both universities through scholar exchange programs. Previously one of the authors from Shanghai spent one year at the US institution; currently one author from the US is visiting the Shanghai institution.

- Assess the student outcomes. This is absolutely essential, especially due to the very technical nature and other unique characteristics of computer science courses

- Continue to develop bilingual materials that best fit different e-learning models and platforms.

\section{REFERENCES}

Chi, E., Klibaner, R. (1999). Designing and developing technology to enhance distance education environments. Reforming the Universities for the 21st Century. July 1999. Beijing, China.

Domanski, B. (1999) On distance learning in computer science using the Internet. Proceedings of ACM SIGCSE Conference, October 1999.

Felder, R.M. (1996). Matters of style. ASEE Prism 6, 4, pp. 18-23 (Dec. 1996).

Hafner, K. (May 2002) Lessons learned at Dot-Com U. New York Times, CIRCUITS, 1.

Klibaner, R., Chi, E., (2003) The virtual university across cultural boundaries: The online classroom - Is the world ready for it? The $7^{\text {th }}$ International Conference on Global Business and Economic Development Strategies for Sustainable Globalization: Business Responses to Regional Demands and Global Opportunities. January, 2003. Bangkok, Thailand

Klibaner, R., Chi, E. (2001). Adapting traditional courses to fully asynchronous e-learning models. The $6^{\text {th }}$ International Conference on Global Business \& Economic Development States and Markets: Forging Partnerships for Sustainable Development. November, 2001. Bratislava, Slovakia,

Picciano, A. (1998). Developing an asynchronous course model at a large, urban university. Journal of Asynchronous Learning Networks, Volume 2, Issue 1, March 1998.

Silberschatz, Korth, \& Sudarshan. (2002). Database system concepts, $4^{\text {th }}$ ed. McGraw Hill. 